\title{
Beyond Netiquette: Digital Citizenship as Participation
}

\author{
Rozália Klára BAKÓ \\ Sapientia Hungarian University of Transylvania \\ Cluj-Napoca, Romania \\ e-mail: bakorozalia@uni.sapientia.ro
}

\begin{abstract}
Digital citizenship research has been on the agenda of scholars and practitioners since 1999 and has been trending since 2015. A plethora of approaches and definitions have been arising, with two major directions: a theoretical-methodological and a practical-educative. The present critical literature review is aimed at advocating for a more civic approach to the issue of digital citizenship and at presenting arguments in favour of a research agenda focused on the participatory components of digital life. Our desk research operated with both original studies and meta-analyses related to the concept of digital citizenship. While being technically savvy and well-behaved online is a key requirement for today's netizen, becoming a citizen in virtual spaces requires more. Beyond netiquette, civic participation online is becoming a core competence.
\end{abstract}

Keywords: digital citizenship, digital life, participation, critical literature review

\section{Rationale and Methodology}

Why the increasing interest towards the issue of digital citizenship? As the Internet is becoming part of our lives, opportunities and challenges of an overwhelmingly digital life take up significant space within the public arena (Council of Europe, 2018; Frau-Meigs et al., 2015; Pathways for Prosperity Commission, 2018; Pew Research Center, 2014; Ram et al., 2020; Suzor, 2019).

With such a wide palette of approaches, from the theoretical and methodological to the practical-educational ones, why another review article? Our experience as researchers and educators has shown that basic and advanced digital literacy skills are necessary yet not sufficient for a competent and ethical engagement in digital life: a civic attitude and the ability to critically understand online interactions is necessary. A well-rounded approach to digital citizenship should be part of the research agenda, and a critical literature review might be instrumental to advocate for it. 
The present critical literature review operates with both original research studies and with meta-analyses summarizing articles on the topic of digital citizenship. It is a desk research carried out from 15 July to 31 October 2021. Articles were selected upon relevance using the Google Scholar database, with the keywords "digital citizenship" and "digital life". The first search keyword was chosen as digital citizenship is the key concept of the present critical review, while "digital life" was one of the most overarching concepts encountered while studying information society topics since 2007 onwards, whence the selection.

The process of selecting literature review studies (meta-analyses) and original research articles consisted of two steps: firstly, the 50 most relevant articles were chosen and categorized for the digital citizenship concept; secondly, the 50 most relevant articles were gathered and categorized for the digital life concept. Based on the quality of the topic analysis, a number of 25 articles were included in the critical literature review, as shown in Table 1 below.

Table 1. Articles included in the review, by relevance categories

\begin{tabular}{ll}
\hline Articles & Relevance categories \\
\hline Atif and Choi, 2018; Choi, 2016; Council of Europe, & \\
2018; Frau-Meigs, O’Neill, Soriani, and Tomé, 2017; & \\
$\begin{array}{l}\text { Işikli, 2015; Pathways for Prosperity Commission, } \\
\text { 2018; Pew Research Center, 2014; Ribble, 2015; Suzor, }\end{array}$ & Thorough theoretical analysis \\
2019; Webler and Tuler, 2000 & \\
\hline $\begin{array}{l}\text { Al-Zahrani, 2015; Choi, Glassman, and Cristol, 2017; } \\
\text { Ram, Yang, Cho, Brinberg, Muirhead, Reeves, and }\end{array}$ & $\begin{array}{l}\text { Thorough methodological } \\
\text { Robinson, 2020 }\end{array}$ \\
$\begin{array}{ll}\text { Buchholysis } \\
\text { Figueredo-Canosa, and Fernández-Prados, 2020; Yue, }\end{array}$ & Timely, specific analysis \\
Nekmat, and Beta, 2019 & \\
\hline $\begin{array}{l}\text { Chen, Mirpuri, Rao, and Law, 2021; Fernández-Prados, } \\
\text { Lozano-Diaz, and Ainz-Galende, 2021; Öztürk, 2021 }\end{array}$ & Thorough meta-analysis \\
\hline $\begin{array}{l}\text { Emejulu and McGregor, 2019; Mossberger, Tolbert, and } \\
\text { McNeal, 2008; Ohler, 2010; Ribble and Bailey, 2007; }\end{array}$ & $\begin{array}{l}\text { Part of a thorough meta- } \\
\text { Richards, 2010 }\end{array}$ \\
\hline
\end{tabular}

Suzor (2019: 39) warns that the Internet has no immune system to protect users against abuse, wherefore it is critical to rely on educated users since online platforms often present themselves as neutral spaces and push responsibility on content creators. However, many of the Internet users are underage, unprepared to take responsibility for their communication practices and online content creation. Children and teenagers are immersed in the digital world yet not fully engaged in it (Bakó, 2019). Their parents and educators are even less connected to digital cultural spaces due to the lack of digital literacy (Bakó-Tőkés, 2018). No wonder 
that education for digital literacy takes up a significant space in conceptualizing and operationalizing "digital citizenship".

\section{Conceptualizing "Digital Citizenship"}

Several research articles and books define digital citizenship with a focus on users' skills (Mossberger-Tolbert-McNeal, 2008; Ribble-Bailey, 2007; Ribble, 2015), while more holistic approaches look into knowledge, skills, attitudes, and values of the digital agora stakeholders (Choi, 2016; Ohler, 2010; Richards, 2010; Emejulu-McGregor, 2019).

In a comprehensive literature review, Fernández-Prados et al. (2021) highlight digital citizenship definitions used by theoretically and methodologically sound studies, as summarized in Table 2 below.

Table 2. Defining digital citizenship

\begin{tabular}{ll}
\hline Authors & Definitions \\
Ribble and Bailey, & $\begin{array}{l}\text { "norms of appropriate, responsible behavior with regard to tech- } \\
\text { nology use. Digital citizenship is a concept which helps tea- } \\
\text { chers, technology leaders, and parents to understand how to use } \\
\text { technology appropriately." }\end{array}$ \\
\hline $\begin{array}{ll}\text { "those who use the Internet regularly and effectively, that is, on } \\
\text { and McNeal, 2008: }\end{array}$ & $\begin{array}{l}\text { a daily basis [...] digital citizens are those who use technology } \\
\text { their civic duty, and who use technology at work for economic } \\
\text { gain" }\end{array}$ \\
\hline Ohler, 2010: 187 & $\begin{array}{l}\text { "character education for the digital age" } \\
\text { "practices conscientious use of technology, demonstrates respon- }\end{array}$ \\
\hline sichards, 2010: 518 use of information, and maintains a good attitude for learn- \\
ing with technology"
\end{tabular}

Source: selected from Fernández-Prados et al. (2021:2) upon variety of approaches

The selected definitions highlight the normative component and the complexity of the "digital citizenship" concept, with technological, educational, and civic activist aspects connected to the digital literacy of the users. 
Research focused on educational aspects rely on Ribble's "nine elements of digital citizenship" (2015:23) providing a practical teaching guide for schools on digital access, digital commerce, digital communication, digital literacy, digital etiquette, digital law, digital rights and responsibilities, digital health and wellness, and digital security. The guide is comprehensive and provides examples of dos and don'ts - hence its popularity.

Methodological approaches were also well received by reviewers and researchers, with a highlight on Choi, Glassman, and Cristol's model of measuring digital citizenship (2017) on a reliable and valid five-factor scale, using a questionnaire with 26 items. The five factors, as presented in Table 3, are structured on three levels or conditions of complexity: technical skills represent a basic, necessary yet not sufficient condition for developing digital citizenship; on the second layer, local and global awareness is an important communicative condition, whereas on a more complex level networking agency, Internet political activism, and a critical perspective is a "collaborative and cooperative condition” of digital citizenship (Choi et al. 2017: 111).

Table 3. Three conditions of complexity when developing digital citizenship

\begin{tabular}{|c|c|c|}
\hline Factors & Description & Level of complexity \\
\hline Technical skills & $\begin{array}{l}\text { Lower levels of media literacy and basic } \\
\text { open source intelligence skills }\end{array}$ & $\begin{array}{l}\text { Necessary but not } \\
\text { sufficient condition }\end{array}$ \\
\hline $\begin{array}{l}\text { Local and global } \\
\text { awareness }\end{array}$ & $\begin{array}{l}\text { Ethical consumption of information that } \\
\text { deals with local and global issues }\end{array}$ & $\begin{array}{l}\text { Distributed and } \\
\text { communicative } \\
\text { condition }\end{array}$ \\
\hline Networking agency & $\begin{array}{l}\text { Higher levels of media and information } \\
\text { literacy }\end{array}$ & \multirow{3}{*}{$\begin{array}{l}\text { Collaborative } \\
\text { and cooperative } \\
\text { condition }\end{array}$} \\
\hline $\begin{array}{l}\text { Internet political } \\
\text { activism }\end{array}$ & $\begin{array}{l}\text { Action-/transformation-oriented } \\
\text { participation }\end{array}$ & \\
\hline Critical perspective & $\begin{array}{l}\text { Rethinking online participation and the } \\
\text { Internet }\end{array}$ & \\
\hline
\end{tabular}

Source: based on Choi, Glassman, and Cristol's visual model (2017: 111)

The measurement scale, be it complex and valid, has its limitations, as the authors themselves admit: the ethical aspects of participation are not detailed enough. Indeed, when it comes to public participation as an important component of democracy and citizen involvement in decision making, competence is a necessary yet not sufficient condition. Ethical conditions of participatory processes have also an important role in creating an inclusive socio-cultural environment for social actors.

The Choi, Glassman, and Cristol (2017) model is a good example of how digital citizenship research should be conducted, by looking both at the basic and advanced digital literacy skills, complemented with participatory attitudes and a critical 
understanding of how the Internet works. If complemented with more comprehensive ethical criteria, such as the Webler-Tuler approach (2000) adapted for online spaces, a well-rounded research agenda could emerge.

Webler and Tuler (2000) have developed a model of competence- and fairnessbased conditions for public participation in decision making, which could and should be integrated into conceptualizing digital citizenship. A well-organized public hearing event, for instance, be it offline or online, should take the following into consideration: are the rules of interaction comprehensive and created in a participatory manner? Is the space of dialogue organized in an inclusive, smooth, accessible manner? The system of fairness and competence rules for a proper participatory process are available in the Appendix section of this article.

\section{Participation as Civic Engagement}

While narrow definitions of online participation focus on active user behaviour on different platforms (Ribble-Bailey, 2007; Mossberger et al., 2008), broader approaches entail the civic component of digital life (Choi, 2016; Choi et al., 2017; Frau-Meigs, 2017).

As the Council of Europe defines it in a series of programmatic documents, digital citizenship is:

the ability to engage competently and positively with digital technologies (creating, working, sharing, socialising, investigating, playing, communicating and learning); participating actively and responsibly (values, skills, attitudes, knowledge and critical understanding) in communities (local, national, global) at all levels (political, economic, social, cultural and intercultural); being involved in a double process of lifelong learning (in formal, informal and non-formal settings); and seamlessly defending human rights and dignity. (Frau-Meigs et al., 2015: 11-12)

This comprehensive definition entails a complex palette of normative criteria focusing on values, attitudes, skills, knowledge, and critical understanding necessary for living in a digital world. Connected to this approach, another key programmatic document, of the Council of Europe (2018), elaborated the context, concept, and model of competences for developing a democratic culture based on dialogue, inclusion, and participation. The model gives a set of values, attitudes, skills as well as knowledge and critical understanding of what is needed for a democratic culture, an ideal type of a citizen. Since our daily lives are increasingly digital, a model of offline citizen should also be applied online. 
Table 4. The 20 competences model for a democratic culture

\begin{tabular}{|c|c|}
\hline Competence & $\begin{array}{l}\text { Description } \\
\end{array}$ \\
\hline \multirow{3}{*}{ Values } & Valuing human dignity and human rights \\
\hline & Valuing cultural diversity \\
\hline & Valuing democracy, justice, fairness, equality, and the rule of law \\
\hline \multirow{6}{*}{ Attitudes } & Openness to cultural otherness, beliefs, and practices \\
\hline & Respect \\
\hline & Civic-mindedness \\
\hline & Responsibility \\
\hline & Self-efficacy \\
\hline & Tolerance of ambiguity \\
\hline \multirow{8}{*}{ Skills } & Autonomous learning skills \\
\hline & Analytical and critical thinking skills \\
\hline & Skills of listening and observing \\
\hline & Empathy \\
\hline & Flexibility and adaptability \\
\hline & Linguistic, communicative, and plurilingual skills \\
\hline & Co-operation skills \\
\hline & Conflict resolution skills \\
\hline \multirow{3}{*}{$\begin{array}{l}\text { Knowledge } \\
\text { and critical } \\
\text { understanding }\end{array}$} & Knowledge and critical understanding of the self \\
\hline & $\begin{array}{l}\text { Knowledge and critical understanding of language and } \\
\text { communication }\end{array}$ \\
\hline & $\begin{array}{l}\text { Knowledge and critical understanding of the world: politics, } \\
\text { law, human rights, cultures, religions, history, media, economies, } \\
\text { environment, and sustainability }\end{array}$ \\
\hline
\end{tabular}

Source: based on the Council of Europe Framework of Competences for Democratic Culture (2018: 38)

Online and offline interactions are strongly connected in civic spaces (Choi, 2016; Ribble, 2015), wherefore education for participation has a key role in developing responsible netizens (Al-Zahrani, 2015; Buchholz et al., 2020; Chen et al., 2021; Hennig-Manzuoli et al., 2019; Işikli, 2015; Öztürk, 2021; Yue et al., 2019). More complex approaches (Choi, 2016; Frau-Meigs et al., 2016; Choi et al., 2017, Lozano-Diaz et al., 2019) enable developing more inclusive and responsive digital citizenship programmes.

Schools and civil society organizations can and should have an active role in promoting digital citizenship programmes for all individuals and groups since the Internet and its complex platforms develop rapidly, and even the savvy individuals need to learn continuously in order to be competent and ethical actors of the cyber-sphere. 


\section{Conclusions}

Digital citizenship research is gaining space both in scholars' and practitioners' scientific dialogue. Despite the variety and complexity of approaches, well-received books and articles, comprehensive meta-analyses reveal clear trends: when it comes to topical focus, educational approaches prevail; methodological approaches are highly appreciated and included in literature reviews. Meanwhile, a tendency to define digital citizenship mainly as digital literacy - with a greater focus on digital skills rather than on values and attitudes - still prevails.

A research agenda focusing on competent and ethical citizen participation online is needed since the difference between merely being civilized and having a civic attitude online is significant. Such an approach would go beyond netiquette and look into the civic attitudes and participatory practices online.

\section{References}

Al-Zahrani, A. (2015). Toward Digital Citizenship: Examining Factors Affecting Participation and Involvement in the Internet Society among Higher Education Students. International Education Studies 8(12): 203-217.

Atif, Y.-Choi, C. (2018). Guest Editorial: Digital Citizenship: Innovations in Education, Practice, and Pedagogy. Educational Technology \& Society 21(1): 152-154.

Bakó, R. K. (2019). Digital Naïves Go Online. Acta Universitatis Sapientiae, Communicatio 6: 121-129. DOI: 10.2478/auscom-2019-0007.

Bakó, R. K.-Tókés, Gy. E. (2018). Parental Mediation and Romanian Young Children's Digital Practices. Revista română de sociologie, serie nouă 29(1-2): 23-36.

Buchholz, B. A.-DeHart, J.-Moorman, J. (2020). Digital Citizenship during a Global Pandemic: Moving Beyond Digital Literacy. Journal of Adolescent \& Adult Literacy 64(1): 11-17.

Chen, L. L.-Mirpuri, S.-Rao, N.-Law, N. (2021). Conceptualization and Measurement of Digital Citizenship across Disciplines. Educational Research Review 33(4): 100379. DOI: 10.1016/j.edurev.2021.100379.

Choi, M. (2016). A Concept Analysis of Digital Citizenship for Democratic Citizenship Education in the Internet Age. Theory \& Research in Social Education 44(4): 565-607. DOI: 10.1080/00933104.2016.1210549.

Choi, M.-Glassman, M.-Cristol, D. (2017). What It Means to Be a Citizen in the Internet Age: Development of a Reliable and Valid Digital Citizenship Scale. Computers $\&$ Education 107: 100-112. DOI: 10.1016/j.compedu.2017.01.002. 
Council of Europe. (2018). Reference Framework of Competences for Democratic Culture. Volume 1. Context, Concepts and Model. Strasbourg: Council of Europe Publishing.

Emejulu, A.-McGregor, C. (2019). Towards a Radical Digital Citizenship in Digital Education. Critical Studies in Education 60(1): 131-147. DOI: 10.1080/ 17508487.2016.1234494.

Fernández-Prados, J. S.-Lozano-Diaz, A.-Ainz-Galende, A. (2021). Measuring Digital Citizenship: A Comparative Analysis. Informatics 8(18): 1-13. DOI: 10.3390/informatics8010018.

Frau-Meigs, D.-O’Neill, B.-Soriani, A.-Tomé, V. (2017). Digital Citizenship Education: Overview and New Perspectives. Volume 1. Strasbourg: Council of Europe Publishing.

Hennig-Manzuoli, C.-Vargas Sánchez, A.-Duque Bedoya, E. (2019). Digital Citizenship: A Theoretical Review of the Concept and Trends. TOJET: The Turkish Online Journal of Educational Technology 18(2): 10-18.

Işikli, Ş. (2015). Digital Citizenship: An Actual Contribution to Theory of Participatory Democracy. AJIT-e: Online Academic Journal of Information Technology 6(18): 21-38. DOI: 10.5824/1309-1581.2015.1.002.x.

Lozano-Diaz, A.-Figueredo-Canosa, V.-Fernández-Prados, J. S. (2020). Sustainable Development Goals and Digital Citizenship. ICIET 2020, 28-30 March 2020, Okayama, Japan. DOI: 10.1145/3395245.3396431.

Mossberger, K.-Tolbert, C. J.-McNeal, R. S. (2008). Digital Citizenship: The Internet Society and Participation. Cambridge, UK: The MIT Press.

Ohler, J. B. (2010). Digital Community, Digital Citizen. Thousand Oaks, CA, USA: Corwin.

Öztürk, G. (2021). Digital Citizenship and Its Teaching: A Literature Review. Journal of Educational Technology \& Online Learning 4(1): 31-45.

Pathways for Prosperity Commission. (2018). Meaningful Connections for the Next 3 Billion. Oxford, UK: Pathways for Prosperity Commission.

Pew Research Center. (2014). Digital Life in 2025. <http://www.pewinternet. org/2014/03/11/digital-life-in-2025/> [Accessed on: 15 August 2021].

Ram, N.-Yang, X.-Cho, M. J.-Brinberg, M.-Muirhead, F.-Reeves, B.-Robinson, T. N. (2020). Screenomics: A New Approach for Observing and Studying Individuals' Digital Lives. Journal of Adolescent Research 35(1): 16-50.

Ribble, M. (2015). Digital Citizenship in Schools: Nine Elements All Students Should Know. Eugene, OR-Arlington, VA: International Society for Technology in Education.

Ribble, M.-Bailey, G. (2007). Digital Citizenship in Schools. Washington, DC, USA: ISTE.

Richards, R. (2010). Digital Citizenship and Web 2.0 Tools. MERLOT Journal of Online Learning and Teaching 6(2): 516-522. 
Suzor, N. P. (2019). Lawless: The Secret Rules That Govern Our Digital Lives. Cambridge: Cambridge University Press.

Webler, T.-Tuler, S. (2000). Fairness and Competence in Citizen Participation: Theoretical Reflections from a Case Study. Administration \& Society 32(5): 566-595.

Yue, A.-Nekmat, E.-Beta, A. R. (2019). Digital Literacy through Digital Citizenship: Online Civic Participation and Public Opinion Evaluation of Youth Minorities in Southeast Asia. Media and Communication 7(2): 100-114. DOI: 10.17645/ mac.v7i2.1899. 


\title{
Appendix 1. Rules of fairness and competence for public participation (Webler-Tuler, 2000: 570, 572)
}

\author{
Discursive Standard Criteria for Fairness \\ Agenda and the process rules
}

Does everyone have an equal chance to:

- put their concerns on the agenda and approve or propose rules for discourse?

- debate and critique proposals for the agenda and the rules?

- influence the final decision about the agenda and the discourse rules?

Moderator and rule enforcement

Does everyone have an equal chance to:

- suggest a moderator and a method for facilitation?

- challenge and support another's suggestion for a moderator and a method for facilitation?

- influence the final selection of moderator and moderation method?

Discussion

Does everyone have an equal chance to:

- be present or represented at the discourse?

- put forth and criticize validity claims about language, facts, norms, and expressions?

Is the method chosen to resolve validity claim redemption dispute consensually chosen before the discourse began?

\section{Discursive Standard Criteria for Competence}

Comprehensibility validity claims

- Does everyone have equal access to the sources for commonly agreed-on standards and definitions?

- Do all participants have an understanding of each others' terms, definitions, and concepts?

- Do disputes about definitions, terms, and concepts take advantage of preestablished reference standards?

Truth validity claims

- Does everyone have equal access to available and relevant systematic knowledge about the objective world?

- Does everyone have equal access to available and relevant anecdotal and intuitive knowledge about the objective world?

- Is uncertainty of factual information considered along with content?

- Are factual claims consistent with the prevailing opinion in expert and local knowledge? 
- Can participants delegate determinations of factual truth to an outside expert panel?

- Are cognitive legal claims examined by legal experts?

Normative validity claims

- Are there implicit barriers that will bias the distribution of interests that participate?

- Is the affected population identified through objective criteria?

- Are people in the general region permitted to decide for themselves if they are affected?

- Is the discovery and the development of mutual understandings of values among all the participants promoted?

- Are factual implications of normative choices considered in practical discourse?

- Do discourse procedures build compromises and the discovery and development of mutual understandings?

- Are normative choices checked for internal consistency?

- Are normative choices checked against laws?

- Are normative choices checked against present expectations?

Truthfulness validity claims

- Is discussion about the authenticity of the speaker's expressive claims promoted?

- Is an examination into the speakers' sincerity promoted?

- Is an examination into the qualities of the situation promoted?

- Are individuals allotted enough time to accurately state and defend their expressive claims?

- Is the scheme used to translate expressive validity claims into regulative or constantive ones acceptable to everyone?

Overarching rules

- Are misunderstandings reduced before reaching for agreement?

- Is the decision as to which validity claims are redeemed by the group made using a technique that was consensually preapproved?

\section{Cite as:}

Bakó, R. K. (2021). Beyond Netiquette: Digital Citizenship as Participation. Acta Universitatis Sapientiae, Communicatio 8: 49-59. DOI: 10.2478/ auscom-2021-0004. 